\title{
THE PACIFIC WAY OF DEVELOPMENT AND CHRISTIAN THEOLOGY
}

\author{
Matt Tomlinson $^{1}$
}

\begin{abstract}
Since the era of national independence in the Pacific Islands, many indigenous leaders have attempted to articulate a 'Pacific Way' aimed at developing island states along lines true to a shared past. Drawing on emblematic regional practices held to foster communalism, dialogue, and consensus, Pacific Way advocates have argued that Oceanic cultures hold the key to their own postcolonial development by drawing on what they share with their neighbours and what distinguishes them from the Western and global. In this article, I describe how some of the most vigorous and sustained attempts to cultivate a Pacific Way - discursively, at least - have arisen in indigenous Christian theology. I ask what the articulation of a Pacific Way accomplishes for the theologians who use such a figure, and what its implications are for understanding development as a practice with an inherently spiritual aspect.
\end{abstract}

Keywords: Christianity; theology; development; Pacific Islands; Pacific Way

\section{INTRODUCTION}

'The Pacific Way' is a term used since the 1970 s to refer to a style of interaction considered both distinctive and unifying to the societies of Oceania. The concept of a Pacific way of doing things has featured prominently in the fields of development, government, arts, religion, and scholarship. In this article, I describe how early articulations of the Pacific Way included theological aspects joined to developmentalist ones, and I argue that discourse about the Pacific Way is now expressed most forcefully in the work of Christian theologians.

This article is divided into three sections. The first is a brief overview of wellknown literature on the Pacific Way and a discussion of its application to development. The second section is a consideration of the pivotal role of the 
Tongan scholar and artist Epeli Hau'ofa in decrying developmentalist visions of the Pacific while also trying to rework them along distinctly theological lines, although he was not a theologian himself. The third section turns to the field of contextual theology and its visions of how Oceania relates to itself as well as to the rest of the world - that is, how the Pacific Way should now be understood.

Fiji's paramount chief and first prime minister, Ratu Sir Kamisese Mara, gave a speech to the United Nations (UN) General Assembly in 1970 in which the term 'Pacific Way' was apparently first used (Mara 1997, xvi). In his speech, Ratu Mara used the term to explain the 'calm and orderly moves to independence ... in Western Samoa, in the Cook Islands, in Nauru, and in Tonga' as well as Fiji (Mara 1997, 238). Undergirding his claim about calm transition is the warrant that political action in the islands depends on conversation and consensus rather than confrontation. As Michael Haas puts it,'The Pacific Way was politi-

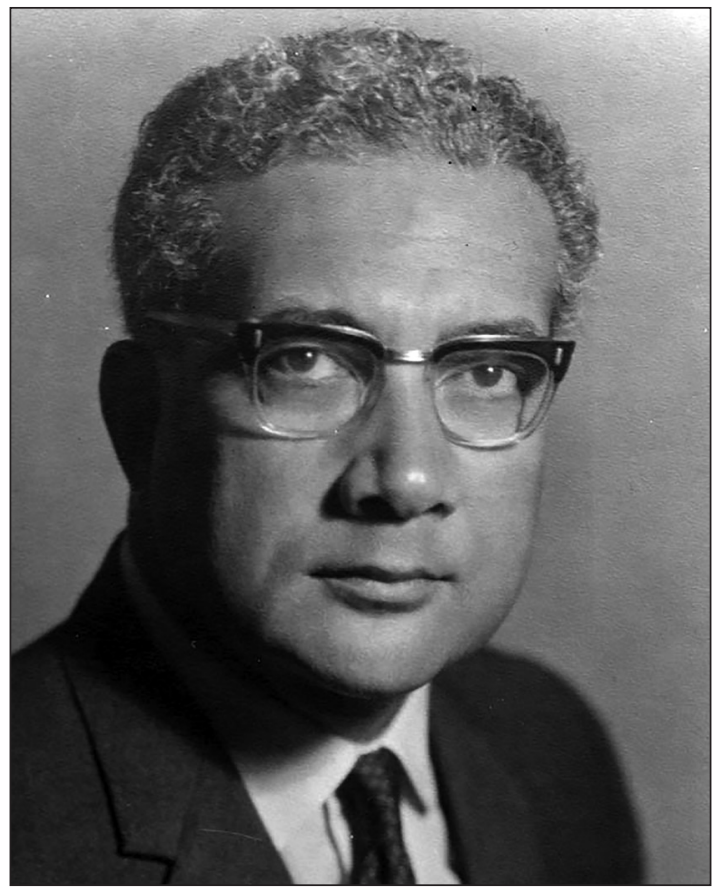

Figure 1. Ratu Sir Kamisese Mara of Fiji. Image from Wikimedia Commons. 
cally motivated - aimed at urging indigenous leaders trained outside the region to unlearn Western modes of conflict resolution' $(1989,9)$.

Stephanie Lawson (2010) points out that Ratu Mara's vision of a Pacific Way differed from the one that gained most currency in the 1970s. As Lawson notes, Ratu Mara's model of consensus was (not surprisingly) an aristocratic one, with wise and powerful chiefs both representing and overseeing the Pacific Way (Lawson 2010). In Fiji, chiefly systems were modified and strongly supported by British colonial practice. In his speech to the UN, Ratu Mara (after offering general criticisms of British colonialism) said, 'when all this has been said, there remains British justice, a sense of fair play, respect for the rule of law, and a basic decency which have left their marks in Fiji $(1997,240)$ - not sentiments one could imagine, say, Frantz Fanon expressing toward France. Yet the kind of Pacific Way advocated at the University of the South Pacific in the 1970s, often associated with Ron Crocombe and his colleagues and students, was explicitly anticolonial. Given Oceania's deep diversity, Crocombe argued, the Pacific Way might not mark internal coherence but, rather, a commonly united opposition to foreign influence: the Pacific Way has an important boundary-marking function, to separate the Pacific from the non-Pacific; to build a protective wall against the overwhelming pressures from non-islanders and non-islands societies, and to provide a basis for some unified action within the wall' $(1976,7-8)$.

Crocombe acknowledged that colonialism in the Pacific had a distasteful legacy, offering its citizens 'a common feeling of deprivation and exploitation', but he also cautioned that a 'new dependency, under multinational corporations and governments which provide "aid", may of course become worse than the old colonial relationship' $(1976,13)$. A volume he co-edited expressed some scepticism about development, such as Jone Dakuvula's quip that 'development planning has its own cult leaders, dogmas and rituals', but the volume generally advocated development along culturally appropriate lines (Dakuvula 1975, 15; Tupouniua, Crocombe, and Slatter, 1975). ${ }^{2}$

Ratu Mara did not frame the Pacific Way as a religious concept. Crocombe, in contrast, pointedly labelled his overview 'The "Theology" of the Pacific Way', and wrote that 'Christianity is very much a part of The Pacific Way' (1976, 1-13, 36). The volume that Crocombe co-edited with Sione Tupouniua and Claire Slatter (1975) offered a trio of chapters on the role of churches in development, with their authors advocating for churches' participation in wider political and social processes. Bishop Patelisio Finau of Tonga referred to the papal encyclicals Rerum Novarum and Quadragesimo Anno to suggest that Christian churches' support for social justice should extend to their involvement in 
processes of development; the bishop added memorably, 'One has to beware lest theology be too heavenly!' $(1975,167)$. Walter Lini, an Anglican priest and Vanuatu's first prime minister, insisted that churches must 'play politics', adding, 'of any type of development which takes place here in the Pacific, we the people of the Pacific must judge whether it is development for justice or for injustice for our people' $(1975,176,177)$. John Mavor referred to the World Council of Churches' (wCC) 1972 report The Role of the Churches in Development to argue that the church must participate in processes of development or risk becoming obsolete. The Pacific Way, in these early postcolonial imaginings, is meant to ensure a fair, locally led, and locally relevant process of development that is also distinctly Christian. ${ }^{3}$

Walter Lini's vision of political and economic development married to justice and spiritual order was famously articulated by Bernard Narokobi as 'The Melanesian Way'. Narokobi characterised the Melanesian Way as 'a total cosmic vision of life in which every event within human consciousness has its personal, communal, spiritual, economic, political and social dimensions. It is, by its very nature, inherently open to change' (1980, 20). Yet he also wrote that because the Melanesian Way is a total vision, it is not only futile, but trite, to attempt a definition of it' (Narokobi 1980, 17). Narokobi, a Catholic with a radically inclusive and reconciling religious sensibility, enthusiastically embraced the ideal of a holistic indigenous spirituality (for example Narokobi 1980, 14-15). As Alex Golub puts it, Narokobi's understanding of the Melanesian Way 'managed to encompass positive valuations of both development and tradition, Christianity and indigenous cosmic orders' (2014, 166; see also Otto 1997). The main themes of his vision for development according to the Melanesian Way were that it must be organised by local values that are not limited to economic growth; it must have a spiritual element; and it must be village-based (Narokobi 1980). He wrote in an article titled 'Nobility of Village Life, 'some people think that modern economic development that is based on European methods of study, experiment, and research is the basis of modern science and technology, and has nothing to do with God and the Bible, and even less so the villages. This is a mistake' (Narokobi 1974, 57-58; see also Boseto 1977). ${ }^{4}$

A key point about these 1970s discourses - whether about the Pacific Way or Melanesian Way, and whether they were religiously inflected or not - is that they offered a jolt of inspiration in the early days of indigenous national sovereignty. The Pacific Way sparked imaginations, including imaginations about development. The Samoan historian Malama Meleisea recalls that for Pacific students in the early 1970s, the Pacific Way and Melanesian Way 'represented exciting ideals. We hoped to achieve unity to create alliances and solidarity in 
the region in which small island states emerging from colonial domination might join forces against neo-colonial influences' (1987, 145; see also Meleisea and Schoeffel 2017, 337-338). ${ }^{5}$ Similarly, Epeli Hau'ofa (whose work I discuss in the next section) recalled that when he arrived at the University of the South Pacific in 1975,

the campus was abuzz with creativity and wide-ranging discussions generated by the emergence of the Pacific Way. Whatever one may say about it the Pacific Way was a large and encompassing idea that became the ideology of its time, perfectly suited to the immediate postcolonial euphoria and expectations of the 1970s. (1993a, 126)

There are two caveats to the preceding discussion. First, not all indigenous intellectuals have found the discourse convincing. For example, the collection of writings by Narokobi (1980, 246-276) includes a section featuring criticism he received. More recently, Feleterika Nokise described the Pacific Way as at best a convenient generalised slogan reserved for political diplomacy and at worst a misleading description of something that actually does not exist' (2011, 100-101). ${ }^{6}$ Second, a full analysis of the Pacific Way and Melanesian Way would need to articulate such discourse with that from other decolonising regions. Oceania was not the only place where understandings of inherent unity took shape in quests to find something transcending geographical boundaries and defining what might be called, loosely, a regional soul or spirit for its peoples. Kwame Nkrumah famously advocated pan-Africanism and wrote that whenever he met other Africans, he realised how much they shared: 'It is not just our colonial past, or the fact that we have aims in common, it is something which goes far deeper. I can best describe it as a sense of one-ness in that we are Africans' (Nkrumah 1963, 132; emphasis in original). Intellectually, the step from Nkrumah to Narokobi is a short one, but in this article I do not attempt to trace the ways and moments in which their genealogies intersected. ${ }^{7}$

EXPANDING OCEANIA

The Oceanic world is woven together through histories of migration, trade, marriage, warfare, and evangelisation, reflected today in the resonance of languages, myths, arts and political and religious forms across diverse nations. In Crocombe's words, 'The Pacific Way is not so much for any particular culture, it is for operation across Pacific cultural boundaries' $(1976,35)$.

As mentioned above, Epeli Hau'ofa wrote of arriving at the University of the South Pacific in 1975 to find the place buzzing with postcolonial excitement 
about the Pacific Way. Ratu Mara had delivered his speech to the United Nations five years earlier; a five-day conference in 1973 led to the publication of the development-oriented volume co-edited by Tupouniua, Crocombe, and Slatter (1975); and in 1976 Crocombe published his own booklet. The title of both these works from the mid-197os, as well as Ratu Mara's memoirs published in 1997 , is The Pacific Way.

Another key voice from that luminous historical moment was Albert Wendt, the Samoan novelist and poet, who said some of what Epeli Hau'ofa would say a decade and a half later, and said it with equal verve and beauty. In his article 'Towards a New Oceania, published in the first issue of the journal Mana Review, Wendt describes geography as a product of the imagination - 'our countries, cultures, nations, planets are what we imagine them to be' - and he urges a reimagining of Oceania: 'So vast, so fabulously varied a scatter of islands, nations, cultures, mythologies and myths, so dazzling a creature, Oceania deserves more than an attempt at mundane fact; only the imagination in free flight can hope - if not to contain her - to grasp some of her shape, plumage, and pain' $(1976,49)$. Yet Wendt was critical of 'glib' invocations of the Pacific Way for, he observed, 'there is much racial discrimination between our many ethnic groups, and much heartless exploitation of one group by another' $(1976,53)$.

Wendt emphasised the need for control over representations of Oceania and the ability of Pacific Islanders to exercise agency in the wider world. As he put it, 'we, mini in size though our countries are, must try and assume control of our destinies, both in utterance and in fact' (Wendt 1976, 51). The watershed essay by Epeli Hau'ofa, 'Our Sea of Islands' (1993b), expressed this same sentiment but challenged the idea that Oceanic nations were miniature in size. Smallness, Hau'ofa argued, 'is a state of mind' (1993b, 7) and can be overcome with divine inspiration. Specifically, one can recapture past visions of 'the underworld with its fire-controlling and earth-shaking denizens, and the heavens above with their hierarchies of powerful gods and named stars and constellations that people could count on to guide their ways across the seas' (Hau'ofa 1993b, 7). Pele, Maui, Kanaloa: these are not modest figures! Hau'ofa also invoked the Christian narrative of Paul's conversion on the road to Damascus to characterise the moment that he saw Oceania in a new and newly powerful way (1993b, 5).

For Hau'ofa, the problem for newly independent Oceanic states was the ideological legacy of colonialism perpetuated in development discourse. Scholars and policymakers who characterise the Pacific Islands as small and remote need to do so, he argued, because they 'are involved directly or indirectly in the fields of aided development and Pacific Rim geopolitics, for the purposes of which 
it is necessary to portray our huge world in tiny, needy bits' (Hau'ofa 1993b, 14). For those who would manage, develop, and perhaps exploit the islands, the islands (seem to) need to be broken up by national borders and ideologically separated from the seas that connect them to each other. Writing against this model, Hau'ofa offered his now-classic poetic celebration of Oceania as a vast, interconnected, and expansive place (see also Hau'ofa 2008).

Yet Hau'ofa did not abandon the ideal of development. In fact, success in development was something he proposed as a demonstration of the real-world effects of reimagining Oceania. He advocated development by turning to the sea: 'Our role in the protection and development of our ocean', he wrote, 'is no mean task; it is no less than a major contribution to the well-being of humankind' (Hau'ofa 1993b, 14). By keeping the rest of the planet healthy, and feeding billions of people, the ocean is vital to all our present needs, including our development needs. And, Hau'ofa added, 'There are no more suitable people on earth to be guardians of the world's largest ocean than those for whom it has been home for generations' (1993b, 14).

A key interlocutor for the development of Hau'ofa's work was the anthropologist Marshall Sahlins. He is the first person thanked by Hau'ofa in the acknowledgments for 'Our Sea of Islands', for convincing me in the end that not all is lost and that the world of Oceania is quite bright despite appearances' (1993b, 16n1). Here, Sahlins' own model of 'development' deserves mention, for it is a distinctly anthropological model built on a robust idea of indigenous agency shaping the engagements that both transform society and reproduce value - which is to say, it is grounded in a cultural logic markedly different from the logics configuring much development theory. Hau'ofa is Sahlinsesque and Sahlins is Hau'ofaesque on this point, if not in all regards. In his essay 'The Economics of Develop-Man in the Pacific', Sahlins (1992) recalls a conversation he heard between two students from Papua New Guinea at the University of the South Pacific in Suva. One of them used the English word 'development' in a Tok Pisin sentence, and pronounced it 'developman', which Sahlins found 'a happy misunderstanding' on his own part, as it seemed 'to express truly the initial relation of Pacific island peoples to the encroaching Western economy' $(1992,13)$.

Still writing about Papua New Guinea - although he goes on to include Pacific Islanders and indeed indigenous peoples in general - Sahlins argues:

Brought into the orbit of the capitalist World System, this global crusade of economic rationality, they have proven themselves quick studies in commercial cunning - which they use to stage the most 
extravagant traditional ceremonies anyone could ever remember. More pigs have been eaten and more pearl shells exchanged in these recent shindigs than was ever done in the good old days, not to mention the liberal consumption of such novelties as beer and tinned corned beef. The effect has been more pleasure for the ancestors, which also means greater power and fame for the living. And let the hard-headed development economists or the neocolonial officials complain as they may, this is neither 'waste' nor 'backwardness'. Precisely, it is development from the perspective of the people concerned: their own culture on a bigger and better scale than they ever had it. (1992, 13; emphasis in original)

Here the resonance with Hau'ofa is remarkable. Both authors share the core idea that there is a grounded set of values, practices, and interrelationships that enables Oceanic expansion. This expansion can be manifest as grander public adherence to tradition or a revaluation of Oceania itself as a place within the world.

Hau'ofa's 'Our Sea of Islands', from the 1990s, is connected to Pacific Way discourse of the 1970s. Both were inspired and inspiring visions of Oceanic expansiveness informed by anthropological concepts of culture. Although Hau'ofa was not a theologian, he is often cited by indigenous theologians from Oceania (see e.g. Bird 2011, 24; Halapua 1998, 30 and 2008, 8-9; Lima 2012, 144-145; Tofaeono 2000, 58, 181; Tuwere 1995; Vaai 2006, 20; Vaka'uta 2011, 31, 71. Note, these authors come from the Solomon Islands, Fiji, Samoa, and Tonga, demonstrating Hau'ofa's regional appeal). He is also cited by many anthropologists, and it bears mention that few authors appeal to both of these audiences so strongly.

One issue on which most of the authors discussed so far did not come to consensus was the religious dimension of the Pacific Way and Oceanic expansiveness. For some authors, religion does not matter at all, nor does it merit a mention. For others, and Hau'ofa especially, the religious dimension is present but in a curious way: made iconic at some moments, sidelined at others. For yet others, a religious dimension - specifically, a Christian one - is vital. In the final section of this article, I consider how Pacific Way discourse has motivated work by indigenous Christian theologians.

\section{THEOLOGICAL ARTICULATIONS}

During the heyday of Pacific Way discourse, a curious interruption took place in Pacific theology. The Pacific Journal of Theology, a journal which has done 
much to promote the vision of Oceania as a unified place (Tomlinson 2015b), did not actually get published at the height of Pacific Way interest. The journal's first series ran from 1962 to 1970 and then closed down. It began publishing again in 1989, and has published its second series continually since then. I do not know why the journal remained dormant during the flowering of Pacific Way consciousness, but its re-emergence in the late 1980s meant that it was ready to develop the themes Epeli Hau'ofa began to offer. ${ }^{8}$

The 1960s and 1970s saw a great deal of theological ferment in Oceania as ecumenism gained strength. Most notably, the Pacific Theological College (PTC) was established in the mid-196os as a non-denominational academic institution training scholars from across Oceania in theology, biblical studies, church history, and pastoral care (Nokise and Szesnat 2015). In recent decades, PTC and The Pacific Journal of Theology have been key proponents of contextual theology, the branch of theology that takes personal experience and social context as the ground of theological engagement. Whereas in classic (systematic) theology, 'anthropology' is the study of human nature informed by biblical accounts such as divine creation and the fall from paradise, in contextual theology 'anthropology' is sociocultural anthropology, and the study of culture is seen as integral to the study of the divine.

Oceanic contextual theology has developed two distinct approaches to Oceania as a subject - and, by implication, to the Pacific Way. One, exemplified in the work of the Fijian Methodist Ilaitia Sevati Tuwere, has been to approach the development of Pacific theology as a conversation among Pacific Islanders and something of inherent interest to the region. The other, exemplified in the work of the Tongan Anglican Winston Halapua, has been to naturalise Oceanic theology and offer it to the world as something the world might learn from. I discuss each of these in turn.

In 1992, Tuwere identified four key themes for emerging Pacific theologies: 'living within the gap' between traditional and modern systems; understanding the history of Oceania in specifically local ways (for example, drawing on Fijian myth) but also articulated with larger understandings of Christian history ('there must be a direct link between Oceania and Israel, not via Sydney or London or Rome'); a focus on place, both landscape and seascape, to articulate indigenous understandings of identity and ecological concerns; and being marginalised, which is a state of 'helplessness' but also an opportunity: 'How can the church be a community of and for the marginalised?' (Tuwere 1992, 49, 50, 52, 54; emphasis in original; see also Gibbs 2010; Tuwere 2002). 


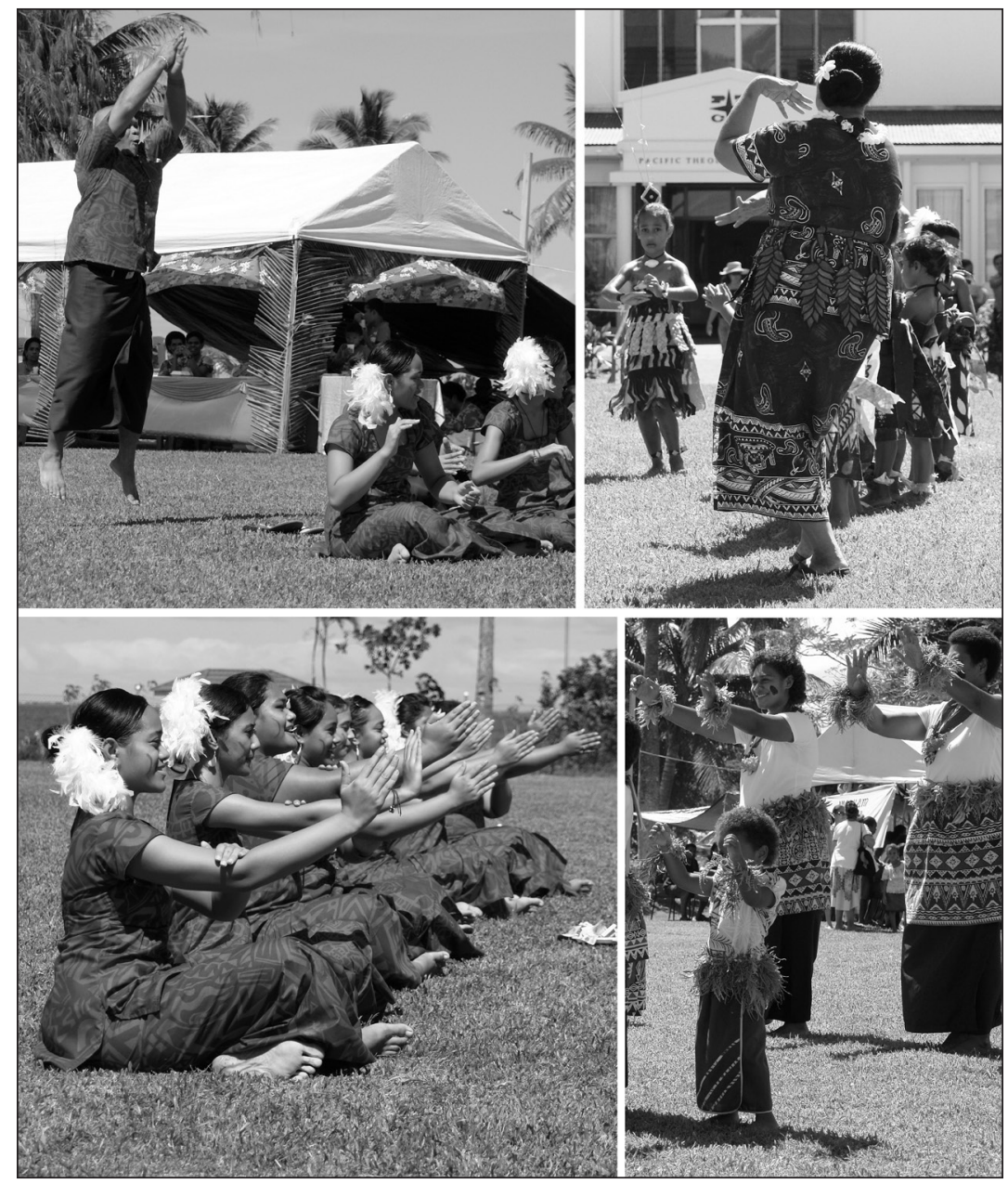

Figure 2. The Pacific Theological College annual bazaar, May 2009. Clockwise from top left: Afereti 'Uili celebrates as a Samoan dance troupe performs; a Tongan dance troupe performs in front of PTC's main administration building; Fijian dance troupe; Samoan dance troupe. Photographs by author.

Tuwere developed these themes over the following decades. One of the most notable moves in his scholarship, and one that has significant implications for any reconstruction of Oceanic intellectual history, is that he initially argued that renewed understandings of the ocean were a key resource for developing a Pacific theology (Tuwere 1990), but later turned to focus more intensively on 
land (see especially Tuwere 2002). I have written elsewhere about aspects of Tuwere's land-based theology (Tomlinson 2015a), which must be seen partly in the context of Tuwere's leadership of the Methodist Church of Fiji during a fraught period between coups in which the Church had been involved. ${ }^{9}$ Here, it is important to note that just as Albert Wendt forms a conceptual pair with Epeli Hau'ofa on the theme of Oceanic expansiveness, so does Ilaitia Sevati Tuwere's early work form a pair with Hau'ofa's on the theme of the ocean being a key resource for thinking through issues of identity, spirituality, and development of various kinds. But unlike Hau'ofa, who kept the ocean in the forefront of his vision with titles such as 'The Ocean in Us' (2000) and We Are the Ocean (2008), Tuwere turned from the ocean back to the land.

The Tongan Anglican Winston Halapua, who worked with Tuwere at St John's College in Auckland, picked up the theme of Oceanic connections to the sea and extended it in a way Tuwere had not. Indeed, Halapua declared:

I write because I believe that concepts and values from Oceania have a wider relevance. Theology has in a sense been landlocked - I write using metaphors arising from the different aspects and waves of the ocean. I write with a deep oceanic sense of interconnectedness with creation, with others and with the mystery of the God who calls into being all things ....

We, as people of Oceania, are an integral part of the world. Although we may be perceived as people far distant and isolated in islands scattered in a vast ocean ... I contend that we speak not as people of the land but people who have been nurtured by the vastness of the ocean and the huge importance in human relationships of life-giving space. (Halapua 2008, 3, 54)

The move Halapua makes by distancing himself from 'people of the land' discourse seems designed to do four things. First, it distinguishes his approach from Tuwere's. Second, it identifies his approach firmly with Hau'ofa's even though, as I noted, there is also resonance between Tuwere's work and Hau'ofa's. Third, his move away from the land and toward the ocean turns it into a regional emblem: the ocean is what Pacific Islanders relate to in a way that makes them globally distinct. Whereas Narokobi appealed to an ancient, holistic Melanesian spirituality based in families and villages, Halapua turns to the ocean as regional icon and source of spiritual wisdom. And fourth, in doing so, he attempts to establish a base from which Pacific Islands theologians can speak with other theologians across the globe. 
It is worth quoting Halapua at length for the way he explicitly draws together an ideal of Pacific regional identity, the emblem of the ocean, and his desire for global theological dialogue. He explains that he calls his approach theomoana, joining theology with the moana, the ocean:

Theomoana is an approach, a conversation or dialogue with theology. As each person in the Oceanic group dance has a part to play within the dance, so each section of the Church has a movement of grace to offer in the worship and mission of God.... [T] his 'movement of grace' from Oceania is offered alongside the work of other thinkers and scholars from different parts of the Church and world....

In the word theomoana - 'God the Ocean' - moana is used to express the world-encompassing, interconnecting nature of God....

As the waves of the oceans of this world break over reefs and embrace the coastlines, so the waves of the God whom we may describe and celebrate as the great moana embrace us without ceasing. Theomoana underlines that our thinking and relating to God are also about our thinking and relating to one another. (Halapua 2008, 91-93) ${ }^{10}$

In Halapua's vision, God is ocean, God is the world, and God is human relationship. This characterisation of divinity puts theologians from the Pacific Islands in a key position, able to speak as people defined by an oceanic environment with its endlessly intersecting waves, and engaging in dialogue with people from other parts of the world (see also Hau'ofa 1993a, 139).

\section{CONCLUSION}

The English-language phrase 'The Pacific Way' is often used to point to a distinctive style of interaction shared by many Pacific Islanders. In the sense of the term that emerged in the 1970s, socioeconomic development of the islands would depend on recognising and strengthening the Pacific Way rather than uncritically importing European models. Although theological aspects of the Pacific Way were not uniformly present in early discussions of the term and concept, Christian thinkers have built upon the core idea of Oceania as an interconnected and expansive place to examine its potential for a new kind of development - a specifically theological development in which Pacific cultural contexts create the possibilities for new kinds of global dialogues.

Socioeconomic development and Christian theology are not mutually exclusive; 
indeed, in some cases they can become so closely aligned as to seem to merge (Fountain and Yoder 2018). Or, one might (try to) co-opt the other: 'Development can be a lot of talk, people shouting a lot of slogans', John Mavor wrote in a textbook-style booklet published in Fiji in 1973; 'It is only the commitment to action by a great number of responsible citizens, by people devoted to Christ[,] that will bring the growth and change that are sorely needed for development to take place' (Mavor 1973,30). Consider also the following lines spoken in 1985, midway between the emergence of Pacific Way discourse in the 1970 and the flowering of Hau'ofa-inspired visions of Oceanic expansiveness in the 1990s:

Let me say right at the start that I believe the Pacific churches are justified in fostering something like a Pacific theology - for exactly the same reasons that we talk about a Pacific Way. The Pacific Way as you know is a way of viewing life and society. It has to do with the way we approach and do things, the way we respect other people, the way we order our priorities, the way we solve problems by consensus rather than argumentation, the basic give-and-take attitude which characterises much of our Pacific culture; in other words our tolerance, the way we share what little we have, that is our generosity. The Pacific Way is a pragmatic philosophy about life in its totality that is distinctly Pacific in character.

... A Pacific Theology to be relevant, effective and reflective of the philosophical and spiritual insights of the peoples of the Pacific will need to be firmly rooted in the rich soil of the Pacific Way. (Tupouniua 1986, 7; emphasis deleted)

This quote is remarkable for two reasons. First, it grounds theological agendas in the Pacific Way, suggesting that the concerns of development agents, politicians, and church intellectuals naturally and necessarily go together. The speaker, responding to messages from the 1970 and anticipating messages from the 1990s, puts them in stereo for a full and harmonious sound that is Christian in its themes and cadences. The second reason the quote is remarkable is because the speaker, although addressing a 'Theological Consultation' sponsored by the Pacific Conference of Churches, was not a theologian, but the Director of the South Pacific Bureau for Economic Cooperation, Mahe Tupouniua.

There is neither neat alignment nor exclusive contrast between developmentalist and theological uses of the Pacific Way, only complicated and changing relationships in which the different uses have influenced each other. I have suggested that, to some extent, theological focus on the Pacific Way has become 
detached from the concerns about politics and development which marked the term's origin. The most recent articulation of the Pacific Way that I have discussed, Winston Halapua's theomoana, seeks to 'develop' theology itself - global theology, with an appreciation of Pacific connections. As Epeli Hau'ofa would surely appreciate, the remarkable thing about Pacific Way discourse is the way it puts Oceania so vibrantly on the map at the middle of things, not only for its own sake but for the sake of the whole world's development.

\section{ACKNOWLEDGEMENTS}

My thanks to Philip Fountain, Geoff Troughton, participants in the Woven Together? conference, and the journal's anonymous reviewers for feedback on this article. All errors are my own. The research on which this article is based was funded by a Future Fellowship from the Australian Research Council, \#FT110100524.

\section{NOTES}

1 Matt Tomlinson is Associate Professor of Anthropology in the Department of Social Anthropology at the University of Oslo, and the College of Asia and the Pacific at the Australian National University. He is the author of the forthcoming book from University of Hawai'i Press, God Is Samoan: Dialogues between Culture and Theology in the Pacific.

Email: matthew.tomlinson@sai.uio.no

2 Ten chapters from the volume, including the ones by Jone Dakuvula and Walter Lini (discussed in the main text), were translated into Fijian by Josua Bogidrau (1982). Crocombe's 1976 booklet was originally published in 1974 as the first article in the first issue of the journal Pacific Perspective.

3 Mavor's reference to the World Council of Churches points to that organisation's key role in fostering the ideas of ecumenism which would prompt the theological dialogues in which Christian understandings of a Pacific Way could develop. In his history of the Pacific Conference of Churches (PCC), a division of the wCC, Charles W. Forman (1986, 1-4, 169-170) identifies several key dates in Pacific ecumenism, including the 1961 meeting at Malua, in Samoa, which launched the PCC, and the 1983 Assembly of the wCC in Vancouver, which had unprecedented Pacific participation and visibility. A key dynamic of the PCC's formation, Forman writes, was its relation with 'world-wide Christian organizations, rather than pan-Pacific secular bodies.... PCC officers went regularly to World Council meetings, carrying news about the Pacific and bringing back news about the rest 
of the world' (1986, 14; see also Forman 2005). And not only news came back money did, too, as wcc funds helped to establish the Pacific Theological College, at which contextual theology has flourished; to hold consultations and conferences at which a distinctly Pacific theology has developed vibrantly; and to support the publication of the Pacific Journal of Theology, which has disseminated these ideas.

4 The Melanesian Way needs to be seen as parallel to the Pacific Way rather than 'subsidiary' to it (pace Durutalo 1992, 207), although much Pacific Way discourse is indeed Polynesia-centric. Narokobi urged his readers to 'build up true solidarity with the Pacific peoples and Pacific nations' $(1980,76)$.

5 Meleisea was responding to Michael Howard's criticism of Walter Lini's advocacy of 'Melanesian Socialism' in Vanuatu. Howard had argued that advocates of the Pacific Way and Melanesian Socialism shared 'virtually the same' aim, namely, 'controlled development which does not threaten the basis of communal village life' (Howard 1983, 186), but that neither had succeeded.

6 In addition, the term 'The Pacific Way' can be used in improvisational and sometimes confrontational ways: 'Once the term was there, and everyone liked the ring of it', Crocombe observed, 'the search was on for meanings to attach to it. You can see it going on unconsciously $[$ sic] at any Pacific-wide meeting, as someone half jokingly attaches the term to some activity or attribute and waits a little anxiously for the response, which is usually also a little defensively jocular, to see if it "took" $(1976,3)$.

7 Nor does Roman Grynberg, despite his suggestion (made in response to the work of Epeli Hau'ofa) that 'In order to give our students hope we must, in the 1990s, resurrect the ghost of Nkrumah in the seas of Oceania' $(1993,71)$.

8 Forman $(1986,33)$ mentions that there were unsuccessful attempts to restart the journal in 1973 and 1977.

9 Tuwere was a moderate, not a supporter of those coups. In thinking and writing about the relationship of people to places within a divine scheme, he was engaging in, among other projects, a subtle analysis of the authority of Fijian chiefs which harmonises in some ways with the work of indigenous Fijian anthropologist Rusiate Nayacakalou (1975).

10 More colloquially, Halapua told the anthropologist Rachel Morgain in an interview, 'Theomoana theology is about relationship, relationship and relationship. There's nothing else but relationship' (Morgain 2014, 78). 


\section{REFERENCES}

Bird, Cliff. 2011. 'Hermeneutics of Ecology and Its Relationship to the Identity of the Oikos in Oceania'. Pacific Journal of Theology, series II, 46:19-33.

Bogidrau, Josua, trans. 1982. Na i Tovo Vakapasifika, 'The Pacific Way'. Suva: Institute of Pacific Studies, University of the South Pacific.

Boseto, Leslie. 1977. 'Mission and Development Cannot Be Separated'. Mission Review, September :10-11.

Crocombe, Ron. 1976. The Pacific Way: An Emerging Identity. 2nd ed. Suva: Lotu Pasifika.

Dakuvula, Jone. 1975. 'Rituals of Planning and Realities of Development'. In The Pacific Way: Social Issues in National Development, edited by S. Tupouniua, R. Crocombe, and C. Slatter, 15-17. Suva: South Pacific Social Sciences Association.

Durutalo, Simione. 1992. 'Anthropology and Authoritarianism in the Pacific Islands'. In Confronting the Margaret Mead Legacy: Scholarship, Empire, and the South Pacific, edited by L. Foerstel and A. Gilliam, 205-232. Philadelphia: Temple University Press.

Finau, Patelisio. 1975. 'Prayer, Persuasion and Politics'. In The Pacific Way: Social Issues in National Development, edited by S. Tupouniua, R. Crocombe, and C. Slatter, 165-175. Suva: South Pacific Social Sciences Association.

Forman, Charles W. 1986. The Voice of Many Waters. Suva: Lotu Pasifika.

- 2005. 'Finding Our Own Voice: The Reinterpreting of Christianity by Oceanian Theologians'. International Bulletin of Missionary Research 29 (3):115122.

Fountain, Philip, and Laura S. Meitzner Yoder. 2018. 'Quietist Techno-Politics: Agricultural Development and Mennonite Mission in Indonesia'. In The Mission of Development: Religion and Technopolitics in Asia, edited by Catherine Scheer, Philip Fountain, and Michael Feener, 214-242. Leiden: Brill.

Gibbs, Philip. 2010. 'Emerging Indigenous Theologies in Oceania'. Concilium 5:34-44. 
Golub, Alex. 2014. Leviathans at the Gold Mine: Creating Indigenous and Corporate Actors in Papua New Guinea. Durham: Duke University Press.

Grynberg, Roman. 1993. 'The Ghost of Nkrumah in the Seas of Oceania'. In A New Oceania: Rediscovering Our Sea of Islands, edited by E. Waddell, V. Naidu, and E. Hau'ofa, 68-71. Suva: School of Social and Economic Development, University of the South Pacific.

Haas, Michael. 1989. The Pacific Way: Regional Cooperation in the South Pacific. New York: Praeger.

Halapua, Winston. 1998. 'Fakakakato: Symbols in a Pacific Context'. Pacific Journal of Theology, series II, 20:21-32.

- 2008. Waves of God's Embrace: Sacred Perspectives from the Ocean. London: Canterbury Press Norwich.

Hau’ofa, Epeli. 1993a. 'A Beginning' In A New Oceania: Rediscovering Our Sea of Islands, edited by E. Waddell, V. Naidu, and E. Hau'ofa, 126-139. Suva: School of Social and Economic Development, University of the South Pacific.

- 1993b. 'Our Sea of Islands'. In A New Oceania: Rediscovering Our Sea of Islands, edited by E. Waddell, V. Naidu, and E. Hau'ofa, 2-16. Suva: School of Social and Economic Development, University of the South Pacific.

- 2000. 'The Ocean in Us'. In Culture and Sustainable Development in the Pacific, edited by A. Hooper, 32-43. Canberra: ANU E Press and Asia Pacific Press.

- 2008. We Are the Ocean: Selected Works. Honolulu: University of Hawai' $\mathrm{i}$ Press.

Howard, Michael. 1983. 'Vanuatu: The Myth of Melanesian Socialism'. Labour, Capital and Society $16(2): 176-203$.

Lawson, Stephanie. 2010. “The Pacific Way” as Postcolonial Discourse'. Journal of Pacific History 45 (3):297-314.

Lima, Peletisala. 2012. 'Performing a Remigrant Theology: Sons and Daughters Improvising on the Return Home'. Ph.D. dissertation, Charles Sturt University. 
Lini, Walter. 1975. 'Should the Church Play Politics?' In The Pacific Way: Social Issues in National Development, edited by S. Tupouniua, R. Crocombe, and C. Slatter, 176-177. Suva: South Pacific Social Sciences Association.

Mara, Ratu Sir Kamisese. 1997. The Pacific Way: A Memoir. Honolulu: University of Hawai'i Press.

Mavor, John E. 1973. Development $=$ Growth + Change: Five Studies on the Theme of Development. Suva: Lotu Pasifika.

- 1975. 'Is the Church Obsolete?' In The Pacific Way: Social Issues in National Development, edited by S. Tupouniua, R. Crocombe, and C. Slatter, 178-182. Suva: South Pacific Social Sciences Association.

Meleisea, Malama. 1987. 'Ideology in Pacific Studies: A Personal View'. In Class and Culture in the South Pacific, edited by A. Hooper, S. Britton, R. Crocombe, J. Huntsman, and C. Macpherson, 140-152. Auckland and Suva: Centre for Pacific Studies at the University of Auckland and Institute of Pacific Studies at the University of the South Pacific.

Meleisea, Malama, and Penelope Schoeffel. 2017. 'Forty-Five Years of Pacific Island Studies: Some Reflections'. Oceania 87 (3):337-343.

Morgain, Rachel. 2014. 'Living Water: Christian Theologies and Interethnic Relations in Fiji. The Asia Pacific Journal of Theology 15 (1): 65-84.

Narokobi, Bernard. 1974. 'Nobility of Village Life: The Economic Development and the Political Process in Papua New Guinea'. Catalyst 4(4):55-70.

-1980. The Melanesian Way: Total Cosmic Vision of Life. 2nd ed. Boroko: Institute of Papua New Guinea Studies.

Nayacakalou, R.R. 1975. Leadership in Fiji. Melbourne: Oxford University Press.

Nkrumah, Kwame. 1963. Africa Must Unite. London: Heinemann.

Nokise, Feleterika. 2011. 'Ecumenism and Its Hermeneutical Experience in Oceania'. Pacific Journal of Theology, series II, 46:95-127.

Nokise, Feleterika, and Holger Szesnat. 2015. Oceanic Voyages in Theology and Theological Education: Reflections and Reminiscences in Celebration of the 
5oth Anniversary of the Pacific Theological College. Suva: Pacific Theological College.

Otto, Ton. 1997. 'After the "Tidal Wave": Bernard Narokobi and the Creation of a Melanesian Way'. In Narratives of Nation in the South Pacific, edited by T. Otto and N. Thomas, 33-64. Amsterdam: Harwood Academic.

Sahlins, Marshall. 1992. 'The Economics of Develop-Man in the Pacific'. Res 21:1225.

Tofaeono, Ama'amalele. 20oo. Eco-Theology: Aiga-The Household of Life, A Perspective from Living Myths and Traditions of Samoa. Erlangen: Erlanger Verlag für Mission und Ökumene.

Tomlinson, Matt. 2015a. 'Gender in a Land-Based Theology'. Oceania 85 (1): 79-91.

- 2015b. 'A Preliminary Historical Survey of the Pacific Journal of Theology'. Pacific Journal of Theology, series II, 53:51-66.

Tupouniua, Mahe U. 1986. 'Opening Address: Towards a Relevant Pacific Theology'. In Towards a Relevant Pacific Theology: Theological Consultation, Bergengren House, Suva, 8-12 July 1985, 7-13. Suva: Lotu Pasifika.

Tupouniua, Sione, Ron Crocombe, and Claire Slatter, eds. 1975. The Pacific Way: Social Issues in National Development. Suva: South Pacific Social Sciences Association.

Tuwere, Ilaitia S. 1990. 'He Began in Galilee and Now He Is Here: Thoughts for a Pacific Ocean Theology'. Pacific Journal of Theology, series II, 3:4-9.

-1992. 'Emerging Themes for a Pacific Theology’. Pacific Journal of Theology, series II, 7:49-55.

-1995. 'An Agenda for the Theological Task of the Church in Oceania'. Pacific Journal of Theology, series II, 13:5-12.

- 2002. Vanua: Towards a Fijian Theology of Place. Suva and Auckland: Institute of Pacific Studies at the University of the South Pacific and College of St. John the Evangelist.

Vaai, Upolu Lumā. 2006. 'Faaaloalo: A Theological Reinterpretation of the Doc- 
trine of the Trinity from a Samoan Perspective. Ph.D. dissertation, School of Theology, Griffith University, Brisbane.

Vaka'uta, Nāsili. 2011. Reading Ezra 9-10 Tu'a-Wise: Rethinking Biblical Interpretation in Oceania. Atlanta: Society of Biblical Literature.

Wendt, Albert. 1976. 'Towards a New Oceania'. Mana Review 1 (1): 49-6o. 